\title{
Engrained experience-a comparison of microclimate perception schemata and microclimate measurements in Dutch urban squares
}

\author{
Sanda Lenzholzer
}

Received: 19 February 2009 / Accepted: 10 August 2009/Published online: 18 September 2009

(C) The Author(s) 2009. This article is published with open access at Springerlink.com

\begin{abstract}
Acceptance of public spaces is often guided by perceptual schemata. Such schemata also seem to play a role in thermal comfort and microclimate experience. For climate-responsive design with a focus on thermal comfort it is important to acquire knowledge about these schemata. For this purpose, perceived and "real" microclimate situations were compared for three Dutch urban squares. People were asked about their long-term microclimate perceptions, which resulted in "cognitive microclimate maps". These were compared with mapped microclimate data from measurements representing the common microclimate when people stay outdoors. The comparison revealed some unexpected low matches; people clearly overestimated the influence of the wind. Therefore, a second assumption was developed: that it is the more salient wind situations that become engrained in people's memory. A comparison using measurement data from windy days shows better matches. This suggests that these more salient situations play a role in the microclimate schemata that people develop about urban places. The consequences from this study for urban design are twofold. Firstly, urban design should address not only the "real" problems, but, more prominently, the "perceived" problems. Secondly, microclimate simulations addressing thermal comfort issues in urban spaces should focus on these perceived, salient situations.
\end{abstract}

Electronic supplementary material The online version of this article (doi:10.1007/s00484-009-0262-z) contains supplementary material, which is available to authorized users.

S. Lenzholzer $(\bowtie)$

Chair group Landscape Architecture, Wageningen University,

Building no. 101, Droevendaalsesteeg 3,

6708 PB Wageningen, The Netherlands

e-mail: sanda.lenzholzer@wur.nl
Keywords Urban microclimate $\cdot$ Thermal comfort . Perception $\cdot$ Schema $\cdot$ Urban design

\section{Introduction}

The sojourn quality of public spaces is very important for cities because these places influence the image and attractiveness of cities to a great extent (Hajer and Reijndorp 2001; Schäfer 2002). Often, the acceptance of public spaces depends on the mental "images" or "schemata" that people have developed about such places (Lang 1987, pp 135144). In addition, the use of public spaces is also influenced by other factors, one of which is microclimate (Gehl 1987; Eliasson et al. 2007).

It seems that people are often comfortable with the microclimate that they encounter when they use outdoor spaces. This is due mostly to the fact that people use these spaces under rather mild micro-weather circumstances for sojourn, whereas in more extreme situations they try to avoid outdoor environments (Nikolopoulou et al. 2001; Eliasson et al. 2007). More clement weather circumstances are thus the most common situations that people experience in outdoor spaces, especially when they use it for sojourn.

However, there are hints that people are not always that comfortable with the microclimate situation. Public opinion of Dutch urban outdoor spaces indicates that people can be rather critical about microclimate in public spaces. They consider urban squares to be "too windy", "too sunny", etc., and it seems that these ideas often become rather manifest through their long-term experience (Lenzholzer 2008; Coeterier 2000). Indeed, also authors dealing with urban design seem to share similar impressions (Moughtin 1992). This raises questions about the underlying mechanisms of long-term microclimate perception in space and how this 
relates to microclimate "reality"-questions that have not yet been researched in a systematic way.

Actually, it is important to acquire deeper knowledge about these long-term perceptions or "schemata" because they dominate behavioural responses and the acceptance or avoidance of places (Rapoport 1977, pp 178-191; Lang 1987). For urban designers, landscape architects and other professionals who deal with climate-responsive design, for instance, it is very important to know more about the fixed ideas that people have developed about the microclimate of a place since these can be taken into account in a better design of that place.

Furthermore, for microclimate simulations that are supposed to predict outdoor thermal comfort, it is also relevant to have a better informational basis on the microclimate situations that really count from the public's perspective. This can bring about results that are better fitted to people's experience.

The central aim of the study presented here is thus to gather more knowledge about the perceptual microclimate schemata that people develop, and how this relates to the common microclimate circumstances they encounter in urban public spaces.

The concept of perceptual schemata was developed in psychology and is often used in the behavioural sciences and environmental psychology. Schemata can be circumscribed as "images" or "models" of the environment that are strongly shaped by expectations (Neisser 1977, p 22, pp 43-46; Brewer and Treyens 1981; Pezdek et al. 1989). Extensive research into schemata has proven that human behaviour, including the avoidance or preference of places, events, etc., is guided by these schemata and, to a lesser degree, by the actual situation (Kaplan 1973; Lee 1973; Mark et al 1999). However, there is a strong relationship between schemata and "reality", because schemata depend on learning (Neisser 1977, p 54). The learning processes that shape schemata about places also rely on interpretation of environmental "cues", which are physical objects, events or circumstances in the real environment. Brunswick explains his concept of cues through his "lens-model", where the cues are basically "lenses" through which the environment is read or interpreted (Brunswik 1956; Ittelson et al. 1974).

Perceptual schemata, although being subject to change through learning, can linger for a long time - even when the "real" situation has changed for a long time already. This can result in distorted perceptions and misinterpretations (Gould 1973; Bechtel 1997).

The approach of this study is essentially different from earlier approaches used to get to grips with outdoor thermal comfort. Most previous studies have focussed on the physical and physiological aspects of thermal comfort. Thermal comfort models have developed from simple models like "vapour pressure" or "equivalent temperature" towards models including human physiological processes and clothing degree, such as the Predicted Mean Vote (PMV) developed by Fanger (1970), which is commonly used for the prediction of indoor climate. For outdoor climate, other specific indices, such as the Physiologically Equivalent Temperature (Mayer and Höppe 1987; Mayer 1993) and COMFA (Brown and Gillespie 1995), have been developed. Most models have been designed to assess steady state energy balance conditions but more recent research tries to generate more dynamic models (Höppe 2002; Bruse 2005).

In addition, the experiential aspects of thermal comfort have gained more interest recently. Physiological models were compared to the actual thermal experience "Actual Sensation Vote" (ASV), in a study by Nikolopoulou and colleagues (Nikolopoulou et al. 2001; Nikolopoulou and Steemers 2003) and later also by others within the European RUROS project (RUROS 2004; Nikolopoulou and Lykoudis 2006). The research on ASV focussed on the instantaneous experience of thermal comfort, and how this can influence the use of outdoor spaces. However, as mentioned earlier, research on schemata has shown that it is often the long-term experience of a place that influences people's use or avoidance of a place. Therefore it was considered necessary to study people's long-term microclimate experience.

The main question addressed in this study is thus: what kind of long-term schemata have people developed about microclimate and how do these relate to microclimatic "reality"?

This issue will be researched according to the main assumption that people's microclimate schemata match with measurement data that represent the common microclimate situations that people experience in urban outdoor places.

\section{Methods}

As a method a comparison of microclimate experience, maps (belonging to the family of "cognitive maps") and mapped results from microclimate measurements are used. The data for this study were derived from fieldwork in three Dutch urban squares, specifically the Spuiplein in Den Haag (the Hague), the Neckerspoel in Eindhoven and the Grote Markt in Groningen; the squares will be described in detail in the following sections. The method of generating cognitive maps and the methods used for measurements and mapping will then be explained.

\section{Study squares}

The squares chosen for the project share some characteristics, such as their size (around $100 \mathrm{~m}$ diameter; Fig. 1). However, in terms of surrounding building structure and 


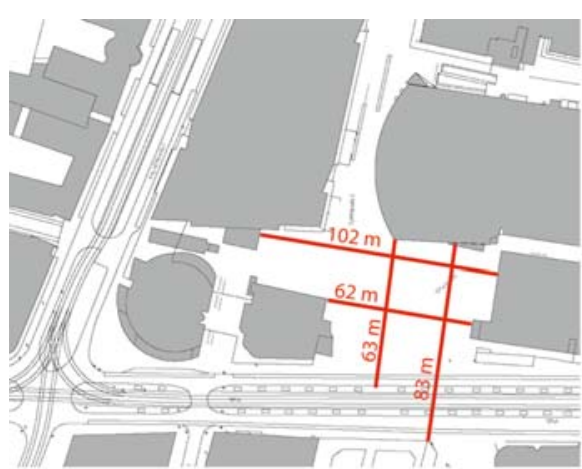

Spuiplein, Den Haag

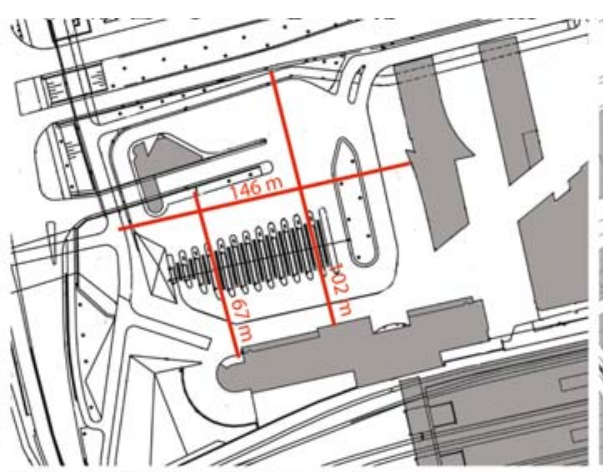

Neckerspoel, Eindhoven

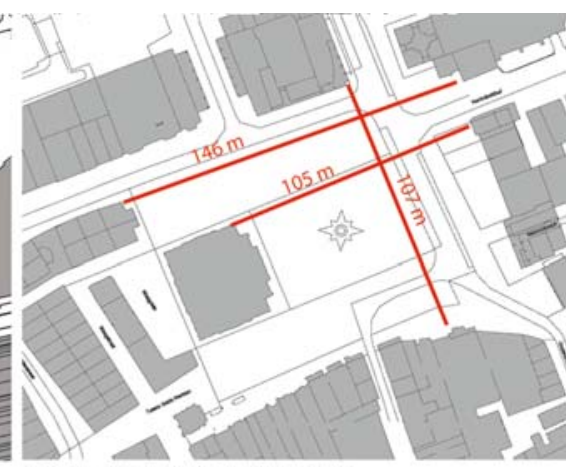

Grote Markt, Groningen

Fig. 1 Case-study squares and their sizes

function, the squares differ substantially (maps with further information on each square can be found in the Electronic Supplementary Material (ESM).

\section{Spuiplein, the Hague}

The Hague (475,580 inhabitants) is the administrative centre of the country. Spuiplein Square $\left(52^{\circ} 04^{\prime} \mathrm{N}\right.$ and $4^{\circ}$ $19^{\prime}$ E, see Fig. 2) is situated in the city centre at a place where several pedestrian routes converge. It is also flanked by a main traffic artery. The square is restricted to pedestrian and bicycle traffic and is well connected to public transport. The square's central area has an eyecatching feature in the summer: a field of about a hundred little fountain jets. Occasionally used for events such as music and sport festivals, most of the time throughout the year it is an open surface without significant activities.

\section{Neckerspoel, Eindhoven}

Eindhoven (210,860 inhabitants) is known as a centre of technological expertise, with the headquarters of Philips and the Technical University of Eindhoven. Neckerspoel
Square $\left(51^{\circ} 25^{\prime} \mathrm{N}\right.$ and $5^{\circ} 28^{\prime} \mathrm{E}$, see Fig. 3), which serves as the main bus terminus of the city, lies on the northern flank of the central railway station building. The main waiting area for passengers lies on the northern side of the station building, where some snack- and flower-shops can also be found. The square allows limited automobile traffic to serve for "kiss and ride" and taxis on the eastern side; the rest of the square is reserved for buses. It should be noted that, just at the time when field-work started, a broad canopy was built to cover large parts of the waiting area, which is very relevant to the thermal comfort of passengers.

\section{Grote Markt, Groningen}

Groningen $(180,908$ inhabitants, of which 42,000 are students) is the administrative and cultural centre of the

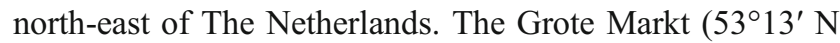
and $6^{\circ} 34^{\prime}$ E, see Fig. 4 ) is the historical main market square of the city and lies in city centre as a part of a sequence of squares. The square features two city landmarks: the Martini church tower, on the north eastern corner, and, on the opposite side, the old town hall. Motor traffic (buses and taxis only) is limited to the eastern side. The rest of the

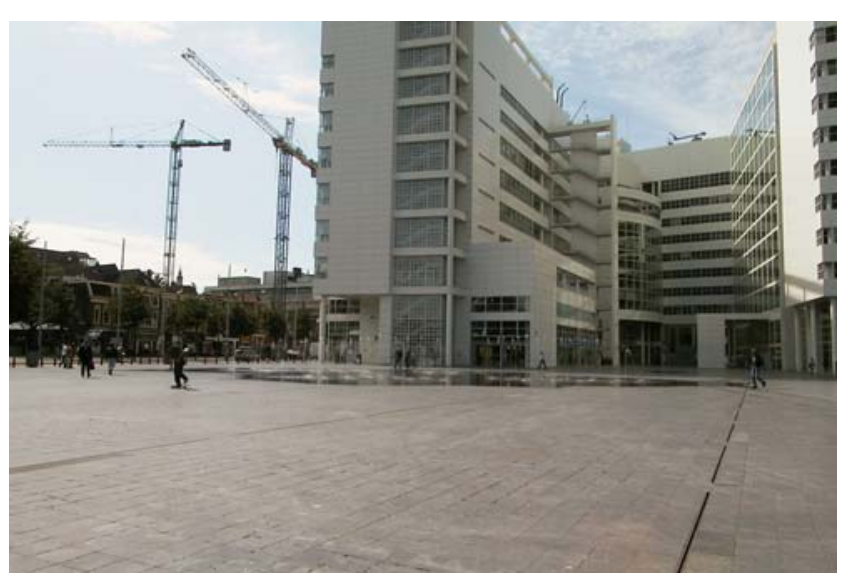

Fig. 2 Spuiplein, Den Haag (the Hague)

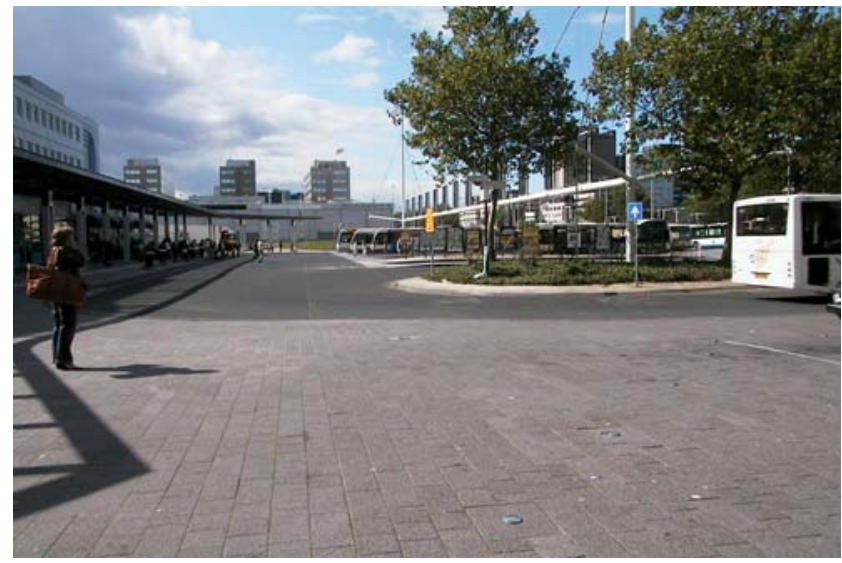

Fig. 3 Neckerspoel, Eindhoven 


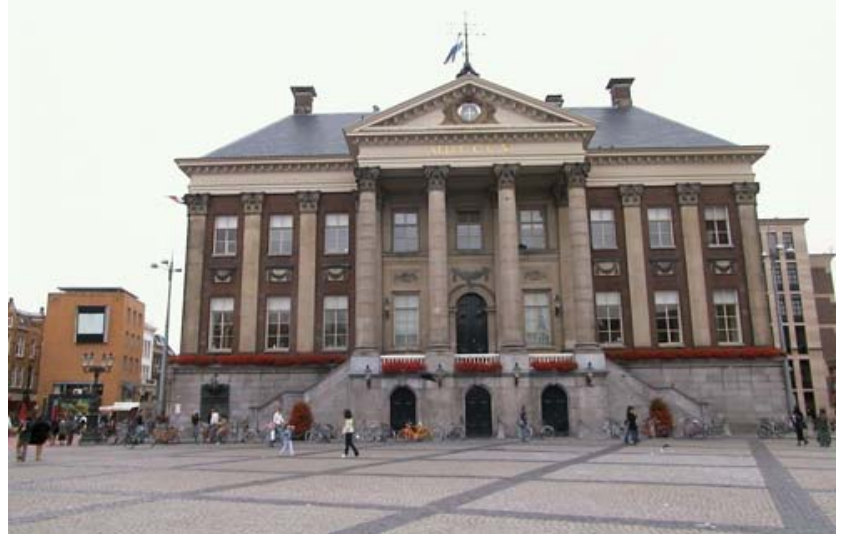

Fig. 4 Grote Markt, Groningen

square is open to pedestrian and bicycle traffic and loading activities related to the market. The market is held on two mornings per week and fun-fairs or events take place a few times per year. But for the majority of the time the square is an open, rather unused place.

\section{Generation of cognitive microclimate maps}

The method of cognitive mapping was identified as a main means to depict primary knowledge about space-related experience (McDonald and Pellegrino 1993; Kitchin 1994). Many cognitive map studies have been conducted on orientation and wayfinding, and on the distortions that occur in people's mental maps (Lynch 1960; Golledge 1992; Tversky 2003). Furthermore, other perceptions of the spatial environment were also studied through cognitive maps, for example Gould's preference mappings for living places in the United States (Gould 1973).

Researchers in the field describe a cognitive map as a spatially configured collection of "schemata" (Kaplan 1973, pp 74-76; Neisser 1977,pp 108-127; Kitchin 1996). This makes the cognitive map method a suitable means for the present study, which tries to relate schemata about microclimate experience to places. For this project, a method similar to Gould's preference-mapping was applied, but on a smaller spatial scale. In this case, cognitive mapping was used to depict people's long-term microclimate experience. This was accomplished by interviews with users of the squares who were already familiar with the place for a longer time.

To gather information about spatial thermal experience patterns, the interviewees were asked to describe locations within the square to which they assign one of several possible microclimate characteristics (see Table 1).

This knowledge was generally expressed about the zones that interviewees knew due to their routines, so the cognitive map produced by an interviewee did not normally cover all parts of the square.
Table 1 Possible reasons for interviewees' microclimate comfort/ discomfort

\begin{tabular}{ll}
\hline Comfort & Discomfort \\
\hline Wind comfortable & Too windy \\
Shade comfortable & Too shady \\
Sun comfortable & Too sunny \\
Good rain-protection & Bad rain-protection \\
Others comfortable & Others uncomfortable \\
\hline
\end{tabular}

The maps from individual interviews were collated to generate collective cognitive maps on the different parameters, e.g. wind, sun, etc. (see Table 1), and were visualised through the GIS application ArcView. Since people did not differentiate their experiences between the different seasons, the maps show one general picture of their long-term experience. People described the zones to which they assigned the above-mentioned microclimate characteristics in a spatially distinct way ("in front of that building there", "on that terrace", etc.), so that the accumulated cognitive maps also show distinct zones (an example can be seen in Fig. 5, for a complete set of accumulated cognitive maps, see ESM).

The series of interviews were conducted in parallel with a series of measurements taken during the outdoor seasons spring, summer and autumn in 2005 and 2006 on 4 days per season. Winter was left out because the research focusses on sojourn in public places and people in The Netherlands do not use public space for sojourn during

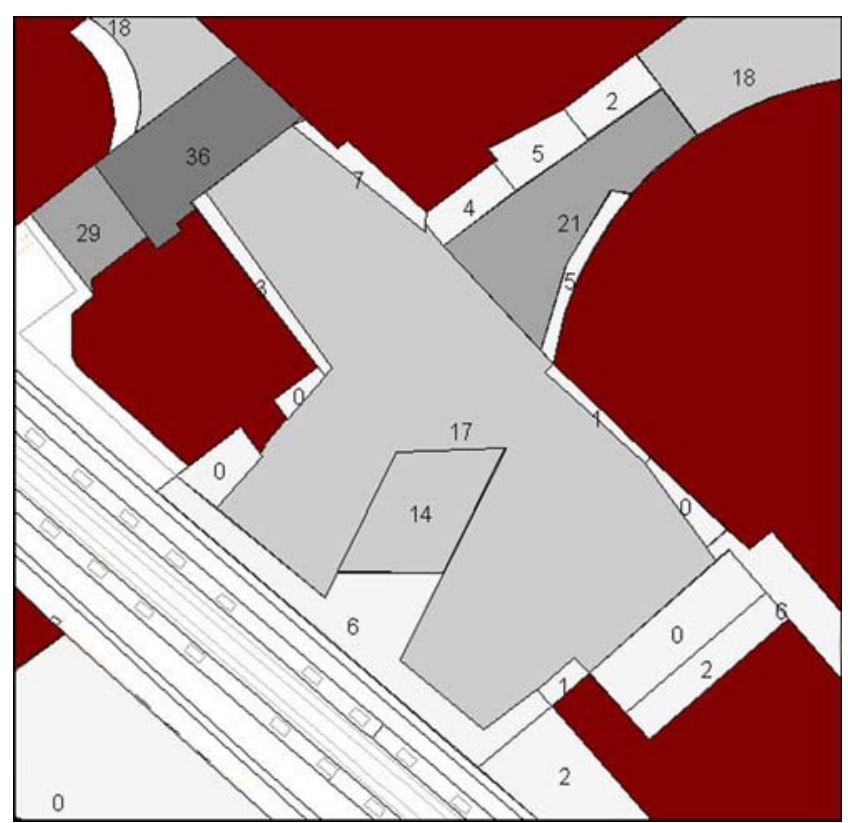

Fig. 5 Example of an accumulated cognitive map: situation "too windy" in Spuiplein, Den Haag 
winter. The interview series resulted in an average of 232 interviews and individual cognitive maps per square (Spuiplein, Den Haag: $n=218$, Neckerspoel, Eindhoven: $n=254$, Grote Markt, Groningen: $n=223$ ).

\section{Measurements and simulations}

Measurements were made to gain insight into the common microclimate situations on site. A comparison of the average weather data from the measurement days taken at the nearby weather stations (www.wetteronline.de) with the long-term climate data from the Dutch Meteorological Institute KNMI (www.knmi/klimatologie/normalen19712000/per_station) shows that the days on which measurements took place were in general days with agreeable weather (with a few exceptions). On days when measurements took place, the averaged maximum air temperatures were higher than the maximum climate averages measured by KNMI, and the averaged wind speeds were lower than the climate averages recorded by KNMI. Specific comparisons can be seen in Table 2. Thus, it can be concluded that the measurement series represents common situations when people use outdoor spaces for sojourn.

A range of data was measured, but most important for the study presented here, which focusses on the parameters shown in Table 1, were wind speed and wind direction. The instruments used were a cup-anemometer and a wind-vane. Measurements were collected on 4 days per each of the three outdoor seasons at $0900,1100,1300,1500$ and 1700 hours. At these time points, measurements were taken at five spots in the square in the Hague and six spots in the squares in Eindhoven and Groningen (see maps with points in ESM under "general information"). The results were visualised using the GIS application ArcView and an example can be seen in Fig. 6. It was not possible to measure the other important microclimate parameter-sun and shadow patterns - in a sufficiently dense grid over the squares. As an alternative, the patterns of sun and shadow were simulated using the 3D-software SketchUp (http:// sketchup.google.com/) for days in the middle of the three seasons (15 April, 15 July and 15 October). An example can be seen in Fig. 7.

\section{Comparison method}

For each of the three squares, two main sets of maps were produced (also see ESM) for the comparisons:

1. maps with the user's long-term microclimate perceptions and reasons (wind, sun, shade, etc.)

2. maps showing the averages of measured wind data and the shadow simulations per season and time slot per day $(0900,1100,1300,1500,1700$ hours)
The accumulated cognitive maps, representing people's schemata, form the starting point of the comparisons. A value of $10 \%$ (of total votes) positive or negative evaluation on the microclimate perceptions per zone was taken as a threshold because lower values might be caused by incidences. All zones that received more than $10 \%$ of the votes were then compared to the measurement- and simulation-maps according to the criteria for matches and mismatches listed in Table 3.

The wind-measurement data were assessed with the help of existing threshold values in order to define if the windsituation was comfortable or not. In the Dutch situation, other researchers have developed threshold values that range between $1.5 \mathrm{~m} / \mathrm{s}$ (Tacken 1989) and $1.8 \mathrm{~m} / \mathrm{s}$ for wind discomfort in stationary activities (Peutz and Associes 2000). Thus, values below 1.5 were considered to be comfortable in terms of wind, values between 1.5 and 1.8 were considered "neutral" and above $1.8 \mathrm{~m} / \mathrm{s}$ was considered to cause wind discomfort. To assess the adequacy of experiences regarding sun or shadow a comparison with the shadow simulation maps was made. For rain protection and other reasons the evaluation had to be based on siteobservations by the researcher because data could not be measured for these parameters. For all parameters, counts were made of the number of matches between the cognitive maps and the measured, simulated and observed mapped data, and expressed in percentages. A value of $100 \%$ means that the experiences matched the measurement data in all cases, and $0 \%$ means that there were no matches between experienced and measured data.

\section{Results and discussion}

The comparison of the cognitive map zones (with votes above $10 \%$ ) with the measured and simulated data is summarised in Table 4.

In the cognitive microclimate maps, a few microclimate parameter zones were considered to be comfortable in terms of "sun". The perceptions of "sun comfortable" sometimes matched with the shadow simulations quite well, e.g. zone 12 in Groningen, which was sun-exposed for very long periods. Another point in the Groningen square, zone 20 (a popular outdoor terrace) was considered to be comfortable in terms of sun, but that was not supported well by the shadow simulations. Here, the reason for people feeling comfort was probably less related to actual sun exposition but rather to the friendly atmosphere of the place. Similar reasons seemed to go for a broad flight of sitting steps in the Hague, zone 4, which was also less sun exposed than people felt. But here also, many people get together and enjoy the atmosphere. Another reason might be the fact that 
Table 2 Comparison of measurement series weather data (from www.wetteronline.de) and general climate data from KNMI Dutch Meteorological Institute (www.knmi/klimatologie/normalen1971-2000/per_station)

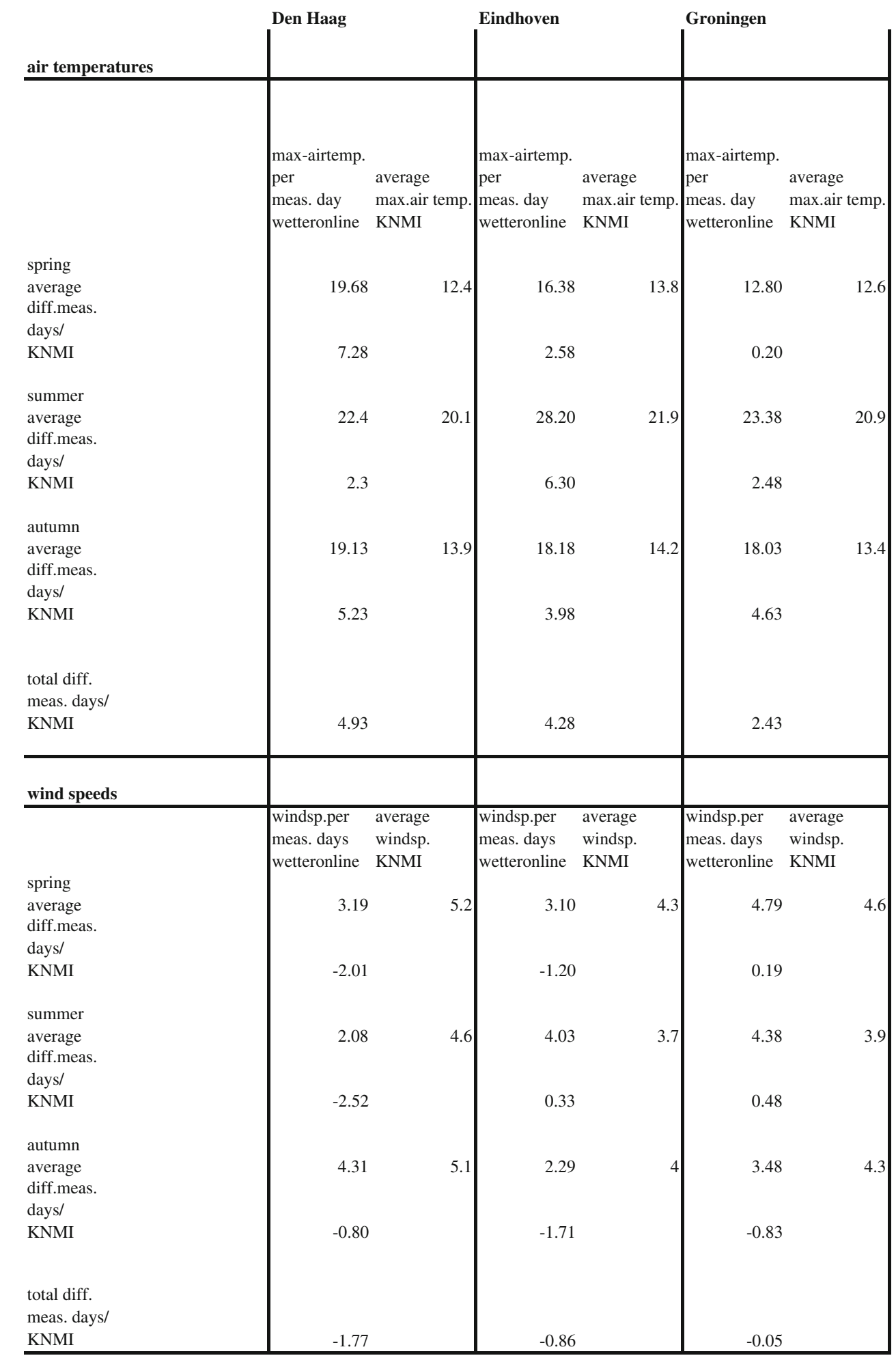




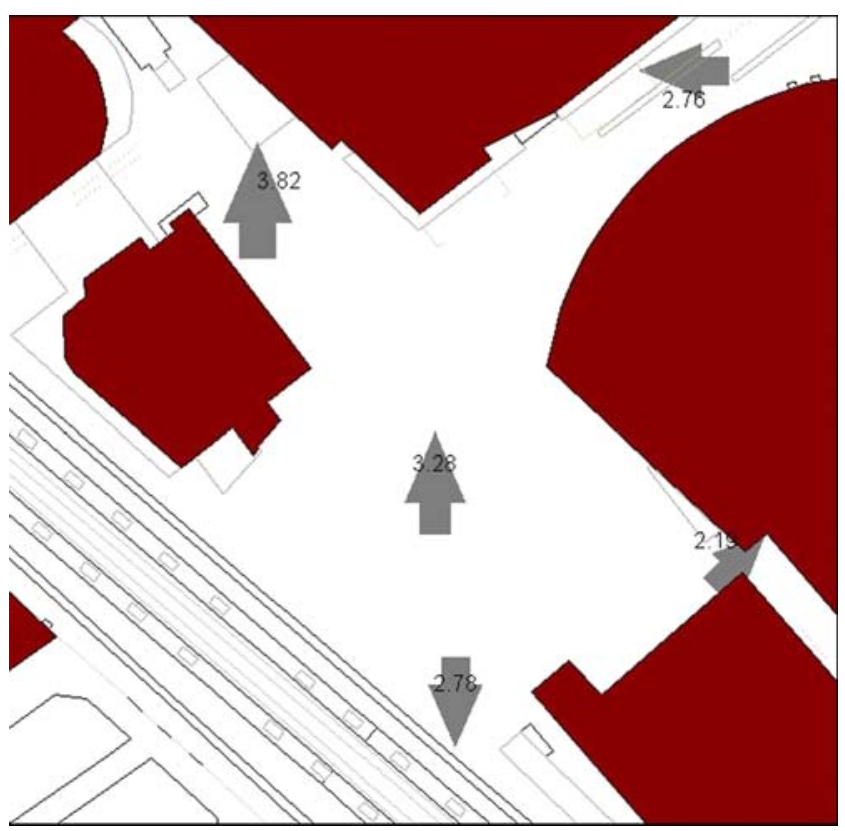

Fig. 6 Example of map derived from wind measurements

the steps were used mostly during lunch breaks when the steps actually did have good sun-exposure.

In Eindhoven, two zones represented the experiences "rain protection good" and "rain protection bad". From onsite observations it was possible to conclude that people's perceptions in those zones were adequate.

The most prominent parameter that got many votes in many zones was the perception "too windy". When the wind perceptions were compared to the averaged measurement data, remarkable discrepancies became apparent. There were several zones that got a high number of mentions in all three squares where the experience of "too windy" and the averaged measurement data did not match. It seemed that people overestimated the influence of wind.

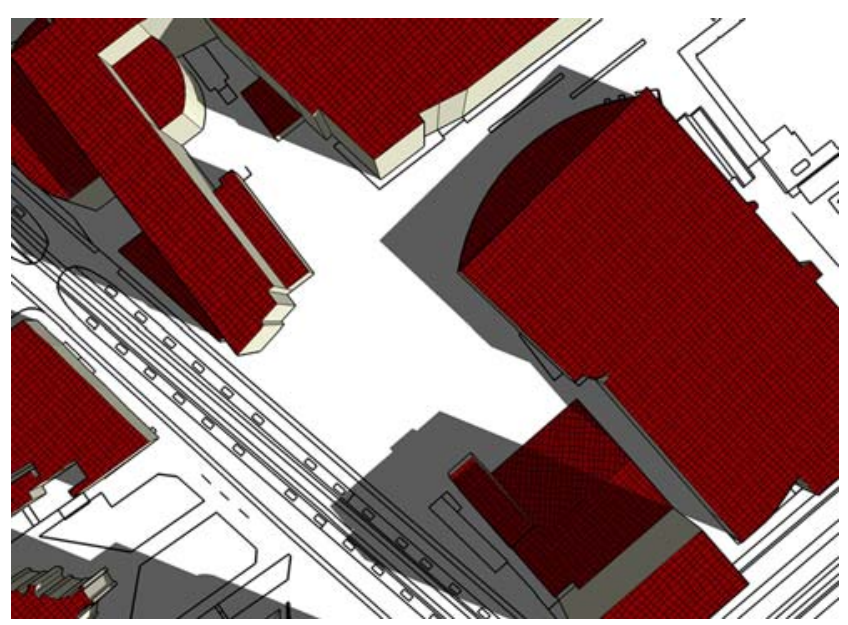

Fig. 7 Example of shadow simulation map
Table 3 Comparison matrix for experience data and measured/ simulated/observed data

\begin{tabular}{ll}
\hline Experience & Measured/simulated/observed \\
\hline $\begin{array}{l}\text { Wind comfort/discomfort } \\
\text { Sun and shadow } \\
\text { comfort/discomfort }\end{array}$ & $\begin{array}{l}\text { Measured wind situation } \\
\text { Rain protection }\end{array}$ \\
$\begin{array}{l}\text { Shadow simulations } \\
\text { Other reasons }\end{array}$ & $\begin{array}{c}\text { of researcher } \\
\text { Assessed by observation } \\
\text { of researcher }\end{array}$ \\
\hline
\end{tabular}

Therefore, the initial assumption that peoples' perceptions match the common microclimate situations was not well supported. This finding raised the question: why is there such a great discrepancy? Is maybe a different mechanism influencing people's microclimate schemata with respect to wind?

To find indicative answers, an alternative assumption was developed, namely that more salient wind events influence people's microclimate schemata. To tentatively test this second assumption, the most windy days of the measurement series were chosen for a second comparison. The days selected were: Spuiplein, the Hague: 3 November 2005; Neckerspoel, Eindhoven: 14 July 2006; Grote Markt, Groningen: 24 May 2006. On these days the wind speeds measured at the nearby weather stations were the highest amongst all the days on which the measurement series took place. The results of comparisons based on this second assumption are shown in Table 5.

The results indicated - and that is not surprising - that the public's cognitive maps for "too windy" situations matched better with maps for stronger wind situations. Thus, the more salient wind situations seem to explain people's microclimate schemata better than the wind events that people encounter throughout the more common situations in public squares. The fact that these more memorable events constitute perception schemata is consistent with psychological theory (Brewer and Treyens 1981; Pezdek et al. 1989). More extreme microclimate situations are not only more memorable but, in case of wind, they are also negative experiences. This "negativity bias" can be explained through the important physiological role of thermal comfort for survival. It is of vital importance for a human being to keep a high awareness and critical attitude towards the thermal environment because it might be life-threatening. In this context, the concept of "threat cues" (Ittelson et al. 1974, p 273) that give hints to a possibly threatening situation also explain this rather negative microclimate schema. Similar "negativity bias" cases have been discussed broadly in the psychological literature (Rozin and Royzman 2001; Baumeister et al. 2001). 
Table 4 Results of comparisons of microclimate perception and averaged measurement/simulation/observation data

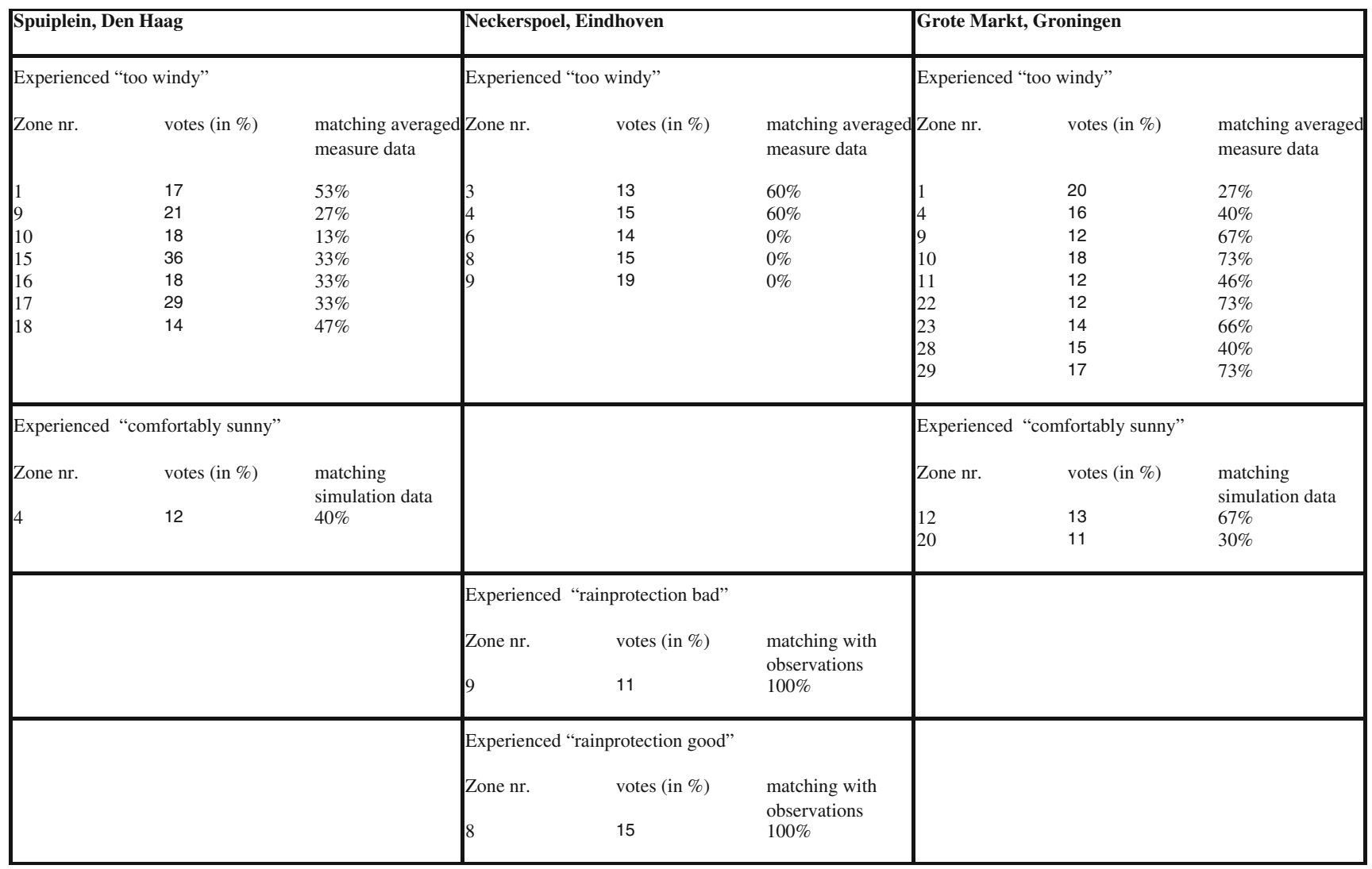

\section{Conclusions}

This study suggests that people have more salient wind situations engrained in their perception schemata on the microclimate in public outdoor places. This negativity bias in wind experience can lead to a rather negative image of a public place and can keep people from using it, which can in turn lead to general neglect of that place. Therefore, it is crucial for urban designers to take action to improve thermal comfort experience in public squares.
The implications for urban design disciplines in the improvement of the thermal comfort experience are twofold. Firstly, the negative schemata that people have often developed have to be counteracted with a strong positive stimulus. Such a kind of counter-stimulus could be, for instance, the creation of more wind-protected spots in places that are interpreted as "too windy" by the public.

Secondly, when microclimate simulations are used in design projects for public spaces, a more "experienceoriented" approach could be used for the choice of input

Table 5 Results of comparisons for wind perception and windy day measurement data

\begin{tabular}{|c|c|c|c|c|c|c|c|c|}
\hline \multicolumn{3}{|c|}{ Spuiplein, Den Haag } & \multicolumn{3}{|c|}{ Neckerspoel, Eindhoven } & \multicolumn{3}{|c|}{ Grote Markt, Groningen } \\
\hline \multicolumn{3}{|c|}{ Experienced "too windy" } & \multicolumn{3}{|c|}{ Experienced "too windy" } & \multicolumn{3}{|c|}{ Experienced "too windy" } \\
\hline Zone nr. & votes (in \%) & $\begin{array}{l}\text { matching windy } \\
\text { day data }\end{array}$ & Zone nr. & votes (in \%) & $\begin{array}{l}\text { matching windy } \\
\text { day data }\end{array}$ & Zone nr. & votes (in \%) & $\begin{array}{l}\text { matching windy } \\
\text { day data }\end{array}$ \\
\hline 1 & 17 & $80 \%$ & 3 & 13 & $80 \%$ & 1 & 20 & $100 \%$ \\
\hline 9 & 21 & $80 \%$ & 4 & 15 & $80 \%$ & 4 & 16 & $80 \%$ \\
\hline 10 & 18 & $80 \%$ & 6 & 14 & $40 \%$ & 9 & 12 & $60 \%$ \\
\hline 15 & 36 & $100 \%$ & 8 & 15 & $40 \%$ & 10 & 18 & $80 \%$ \\
\hline 16 & 18 & $100 \%$ & 9 & 19 & $60 \%$ & 11 & 12 & $80 \%$ \\
\hline 17 & 29 & $80 \%$ & & & & 22 & 12 & $100 \%$ \\
\hline \multirow[t]{3}{*}{18} & 14 & $80 \%$ & & & & 23 & 14 & $80 \%$ \\
\hline & & & & & & 28 & 15 & $60 \%$ \\
\hline & & & & & & 29 & 17 & $100 \%$ \\
\hline
\end{tabular}


data. Currently, average climate data are often used, but according to the outcome of this study it might be advisable to simulate somewhat more extreme wind situations. Such simulations could form a better basis for design with respect to people's comfort perception.

In addition, it might be advisable to conduct some indicative study on the public's cognitive microclimate maps in the analysis phase preceding urban design projects. This information could be very valuable in cases where design should respond to people's microclimate perceptions.

There are still many open questions requiring further research. Firstly, the question arises if people's microclimate schemata in The Netherlands can be transferred to other countries or climate zones. Therefore, it might be worthwhile conducting similar studies to the one described here in other climate zones. For the Dutch situation it would be specifically interesting to study microclimate perception in countries that currently have climate characteristics that can be expected for the future climate in The Netherlands due to climate change.

Although this study revealed some hints regarding people's microclimate schemata and their relationship with "reality", it is important to inquire further into the possible reasons for the remaining mismatches between experienced and measured microclimate situations. Although salient situations explain people's experiences to some degree, still some cases could not be explained by the measured microclimatic situation in this study. Reasons for this could include the atmosphere, the spatial setup, the materialisation of the square, or other parameters. Deeper inquiries into these parameters might yield more useful insights into people's microclimate experience in public spaces.

Acknowledgement Conducting the measurement series would not have been possible without the support of Kassel University, which generously lent out measuring equipment for this study.

Open Access This article is distributed under the terms of the Creative Commons Attribution Noncommercial License which permits any noncommercial use, distribution, and reproduction in any medium, provided the original author(s) and source are credited.

\section{References}

Baumeister RF, Bratslavsky E, Finkenauer C, Vohs KD (2001) Bad is stronger than good. Rev Gen Psychol 5:323-370. doi:10.1037/ 1089-2680.5.4.323

Bechtel RB (1997) Environment and behavior-an introduction. Sage, Thousand Oaks, pp 67-70

Brewer WF, Treyens JC (1981) Role of schemata in memory for places. Cogn Psychol 13:207-230. doi:10.1016/0010-0285(81) 90008-6

Brown RD, TJ Gillespie (1995) Microclimatic landscape design. Wiley, New York
Brunswik E (1956) Perception and the representative design of psychological experiments. University of California Press, Berkeley

Bruse M (2005) Assessing urban microclimate from the user's perspective: multi-agent systems as a new tool in urban meteorology. Ann Meteorol 41:137-140

Coeterier JF (2000) Hoe beleven wij onze omgeving? Resultaten van 25 jaar omgevingspsychologisch onderzoek in stad en landschap (in Dutch). Alterra, Wageningen UR

Eliasson I, Knez I, Westerberg U, Thorsson S, Lindberg F (2007) Climate and behaviour in a Nordic city. Landsc Urban Plan 82:72-84. doi:10.1016/j.landurbanplan.2007.01.020

Fanger PO (1970) Thermal comfort-analysis and applications in environmental engineering. McGraw Hill, New York, pp 19-43

Gehl J (1987) Life between buildings. Van Nostrand Reinhold, New York

Golledge RG (1992) Place recognition and wayfinding: making sense of space. Geoforum 23:199-214. doi:10.1016/0016-7185(92) 90017-X

Gould P (1973) On mental maps. In: Downs R, Stea D (eds) Image and environment-cognitive mapping and spatial behavior. Aldine, Chicago, pp 182-220

Hajer M, Reijndorp A (2001) In search of new public domain. NAi, Rotterdam, pp 7-10

Höppe P (2002) Different aspects of assessing indoor and outdoor thermal comfort. Energy Build 34:661-665. doi:10.1016/S03787788(02)00017-8

Ittelson WH, Proshansky HM, Rivlin LG, Winkel GH (1974) An introduction to environmental psychology. Holt, Rinehart and Winston, New York

Kaplan S (1973) Cognitive maps in perception and thought. In: Downs RM, Stea D (eds) Image and environment - cognitive mapping and spatial behavior. Aldine, Chicago, pp 63-78

Kitchin RM (1994) Cognitive maps: what are they and why study them? Environ Psychol 14:1-19. doi:10.1016/S0272-4944(05) 80194-X

Kitchin RM (1996) Increasing the integrity of cognitive mapping research: appraising conceptual schemata of environment-behavior interaction. Prog Hum Geogr 20:56-84. doi:10.1177/0309 13259602000104

Lang J (1987) Creating architectural theory-the role of behavioral sciences in environmental design. Van Nostrand Reinhold, New York

Lee T (1973) Psychology and living space. In: Downs RM, Stea D (eds) Image and environment - cognitive mapping and spatial behavior. Aldine, Chicago, pp 87-108

Lenzholzer S (2008) A city is not a building — architectural concepts for public square design in Dutch urban climate contexts. J Landsc Archit 5:44-55

Lynch K (1960) The image of the city. MIT Press, Cambridge, MA

Mark DH, Freksa C, Hirtle SC, Lloyd R, Tversky B (1999) Cognitive models on geographical space. Int J Geogr Inf Sci 13(8):747774. doi:10.1080/136588199241003

Mayer H (1993) Urban bioclimatology. Experientia 49:957-963. doi:10.1007/BF02125642

Mayer H, Höppe P (1987) Thermal comfort of man in different urban environments. Theor Appl Climatol 38:43-49. doi:10.1007/ BF00866252

McDonald TP, Pellegrino JW (1993) Psychological perspectives on spatial cognition. In: Gärling T, Golledge RG (eds) Behavior and environment, advances in psychology series 96, North-Holland, Amsterdam

Moughtin C (1992) Urban design—street and square. Butterworth Architecture, London, p 87

Neisser U (1977) Cognition and reality_principles and implications of cognitive psychology. Freeman, San Francisco 
Nikolopoulou M, Lykoudis S (2006) Thermal comfort in outdoor urban spaces: analysis across different European countries. Build Environ 41:1455-1470. doi:10.1016/j.buildenv.2005.05.031

Nikolopoulou M, Steemers K (2003) Thermal comfort and psychological adaptation as a guide for designing urban spaces. Energy Build 35:95-101. doi:10.1016/ S0378-7788(02)0084-1

Nikolopoulou M, Baker N, Steemers K (2001) Thermal comfort in outdoor spaces: understanding the human parameter. Sol Energy 70:227-235. doi:10.1016/S0038-092X(00)00093-1

Pezdek K, Whetstone T, Reynolds K, Askari N, Dougherty T (1989) Memory for real-world-scenes: the role of consistency with schema expectation. J Exp Psychol 15:587-595. doi:10.1037/ 0278-7393.15.4.587

Peutz and Associes (2000) Spuiplein Den Haag — windhinderonderzoek huidige en nieuw te verwachten omliggende bebouwingssituatie, report number OW 86-1, Mook, Zoetemeer
Rapoport A (1977) Human aspects of urban form: towards a manenvironment approach to urban form and design. Pergamon, Oxford

Rozin P, Royzman EB (2001) Negativity bias, negativity dominance and contagion. Personal Soc Psychol Rev 5:296-320. doi:10.1207/S15327957PSPR0504_2

RUROS Project (2004) Rediscovering the urban realm and open spaces, report of the European research project within key action 4 "City of Tomorrow and Cultural Heritage". CRES, Athens

Schäfer R (2002) Urban squares. Callwey/Birkhäuser, Munich/Basel, p 5

Tacken M (1989) A comfortable wind climate for outdoor relaxation in urban areas. Build Environ 24(4):321-324

Tversky B (2003) Structures of mental spaces: how people think about space. Environ Behav 35:66-80. doi:10.1177/0013916502238 865 